\title{
Protection against Endotoxic Shock by Bactericidal/Permeability-increasing Protein in Rats
}

\author{
Hongkui Jin, * Renhui Yang, * Scot Marsters, ${ }^{\ddagger}$ Avi Ashkenazi, ${ }^{\ddagger}$ Stuart Bunting, * Marian N. Marra, ${ }^{\S}$ Randy W. Scott, $§$ \\ and Joffre B. Baker* \\ Departments of ${ }^{*}$ Cardiovascular Research and ${ }^{\ddagger}$ Molecular Biology, Genentech, Inc., South San Francisco, California 94080 ; \\ ${ }^{\S}$ Incyte Pharmaceutical, Inc., Palo Alto, California 94304
}

\begin{abstract}
Bactericidal/permeability-increasing protein (BPI) is a neutrophil primary granule protein that inhibits effects of LPS in vitro. The current study examined the effects of BPI on hemodynamics, mortality, and circulating endotoxin and cytokines in conscious rats with endotoxic shock. Catheters were implanted into the right femoral artery and vein. $1 \mathrm{~d}$ later, human recombinant BPI $(10 \mathrm{mg} / \mathrm{kg})$ or vehicle was intravenously injected immediately, $30 \mathrm{~min}$, or $2 \mathrm{~h}$ after intravenous injection of LPS $(7.5 \mathrm{mg} / \mathrm{kg})$. Mean arterial pressure (MAP) and heart rate were monitored and blood was collected before and after injection. BPI given immediately or 30 min after LPS prevented the LPS-induced reduction in MAP at 4-8 h and markedly reduced mortality. BPI given $2 \mathrm{~h}$ after LPS injection had no protective effect. BPI treated immediately after LPS reduced the circulating levels of endotoxin and IL-6 but increased the circulating levels of TNF. We propose that BPI exerts its protective effect through a TNF-independent mechanism, by inhibiting endotoxin-stimulated production of IL-6. (J. Clin. Invest. 1995. 95:1947-1952.) LPS • septic shock • tumor necrosis factor (TNF) • IL-6 $\cdot$ cytokine
\end{abstract}

\section{Introduction}

Circulatory shock resulting from sepsis has become the most common cause of death in intensive care units $(1,2)$. Despite the complexity of septic shock, endotoxin is generally accepted as a principle bacterial product that is recognized by all mammalian hosts as a major pathogenic entity (2). Endotoxin, a complex of LPS associated with proteins (3), is a major component of the outer membrane of Gram-negative bacteria. When released, endotoxin can cause shock, disseminated intravascular coagulation, multisystem organ failure, and death (4-7). The

Address correspondence to H. Jin, Department of Cardiovascular Research, Genentech, Inc., 460 Point San Bruno Blvd., South San Francisco, CA 94080. Phone: 415-225-1314; FAX: 415-225-6327.

Received for publication 29 June 1993 and in revised form 8 November 1994.

J. Clin. Invest.

(C) The American Society for Clinical Investigation, Inc.

0021-9738/95/04/1947/06 \$2.00

Volume 95, April 1995, 1947-1952
LPS portion of the endotoxin molecule has profound effects on soluble and cellular host inflammatory systems (6). Plasma concentrations of endotoxin correlate positively with severity of disease and mortality in septic patients $(8-10)$.

The bactericidal/permeability-increasing protein (BPI), ${ }^{1}$ one of the neutrophil primary granule proteins, is cytotoxic specifically for Gram-negative bacteria in vitro because of its strong attraction to the outer membrane of the Gram-negative bacterial envelope (11-13). Several lines of evidence indicate that BPI can inhibit effects of LPS in vitro when added extracellularly (14-16). BPI has been shown to bind LPS near the lipid A domain, leading to abrogation of detrimental host responses to LPS (14). BPI also inhibits LPS-stimulated TNF release from monocytes in vitro, and in vivo in the murine lung, and blocks LPS-mediated pyrogenicity in rabbits (16). Further, BPI causes killing of serum-resistant Gram-negative bacteria in vitro and inhibits the bacteria-induced release of TNF in human whole blood (17). Recently, BPI has been found to decrease mortality in mice challenged with endotoxin (18). Taken together, these studies suggest that BPI may have therapeutic potential in severe endotoxemia or endotoxic shock.

The current study was designed to examine the effects of BPI on hemodynamics, mortality, and circulating levels of endotoxin and cytokines in endotoxic shock. We developed a rat model of endotoxic shock in which BP and heart rate (HR) could be observed for $6 \mathrm{~d}$ in the conscious, unrestrained state. We show that BPI inhibits the LPS-induced increase in circulating levels of endotoxin and IL-6, prevents the LPS-induced hypotension, and reduces mortality in endotoxic shock, despite causing elevation in circulating levels of TNF.

\section{Methods}

Male Sprague-Dawley rats aged 9 wk were obtained from Charles River Laboratories (Wilmington, MA). All rats were maintained at constant humidity $(60 \pm 5 \%)$, temperature $\left(24 \pm 1^{\circ} \mathrm{C}\right)$, and light cycle $(0600-$ $1800 \mathrm{~h}$ ) and fed with a standard rat diet. $2 \mathrm{~d}$ after arrival, the rats were anesthetized with Metofane (Pitman-Moore, Inc., Mundelein, IL), and one polyethylene catheter (PE-10 fused with PE-50) filled with heparinsaline solution $(50 \mathrm{U} / \mathrm{ml})$ was implanted into the abdominal aorta through the right femoral artery for measurements of BP and HR. A second was implanted into the right femoral vein for drug administration. The catheters were exteriorized at the back of the neck with the aid of

1. Abbreviations used in this paper: BPI, bactericidal/permeabilityincreasing protein; HR, heart rate; MAP, mean arterial pressure. 

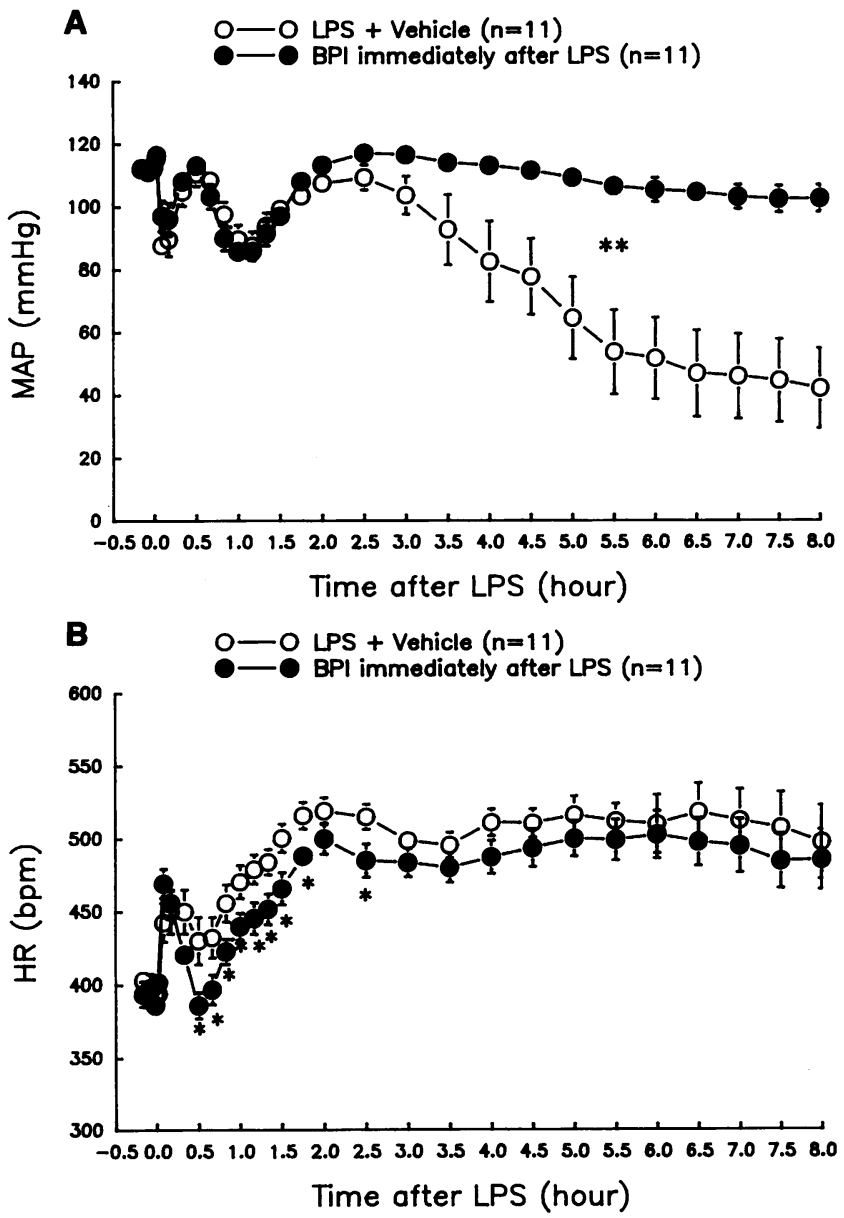

Figure 1. Effects of BPI treatment immediately after LPS injection on MAP and HR. ${ }^{*} P P<0.01$, comparison of MAP at $4-8 \mathrm{~h}$ between the vehicle- and BPI-treated group; $* P<0.05$, compared to the vehicletreated group at the same time point.

a stainless steel wire tunneled subcutaneously and then fixed with fastpolymerizing dental cement. After catheter implantation, all rats were housed individually.

$24 \mathrm{~h}$ after surgery, the arterial catheter was connected to a pressure transducer (CP-01; Century Technology Co. Inc., Inglewood, CA) coupled to a polygraph (Model 7; Grass Instruments Co., Quincy, MA). Mean arterial pressure (MAP) and HR were monitored simultaneously in conscious, unrestrained rats. After a 45-min stabilization period, each rat received a bolus injection of LPS $(7.5 \mathrm{mg} / \mathrm{kg}$ ) (from Escherichia coli serotype 0127:B8; Sigma Chemical Co., St. Louis, MO). A pilot study had shown that the LPS at this dose caused $85-90 \%$ death in 24 $\mathrm{h}$ in rats. Human recombinant BPI $(10 \mathrm{mg} / \mathrm{kg}$ ) (Incyte Pharmaceutical, Inc., Palo Alto, CA) or vehicle was intravenously administered as bolus injection immediately, $30 \mathrm{~min}$, or $2 \mathrm{~h}$ after LPS injection. Previous studies demonstrated that BPI administered intravenously at doses up to $10 \mathrm{mg} / \mathrm{kg}$ produced no acute hematologic, biochemical, or pathologic abnormalities in mice or Sprague-Dawley rats $(18,19)$. MAP and HR were monitored after injection of LPS and BPI or vehicle. If the rat survived, MAP and HR were measured daily for $6 \mathrm{~d}$.

To avoid influences of blood loss on hemodynamics, blood collections were performed in separate groups of rats. The rats were catheterized as above. $24 \mathrm{~h}$ after surgery, BPI $(10 \mathrm{mg} / \mathrm{kg})$ or vehicle was intravenously injected immediately after the LPS $(7.5 \mathrm{mg} / \mathrm{kg})$ injection. Blood $(0.5 \mathrm{ml})$ was collected through the arterial catheter $5 \mathrm{~min}$ before and after injection. An equal volume of saline was intravenously injected

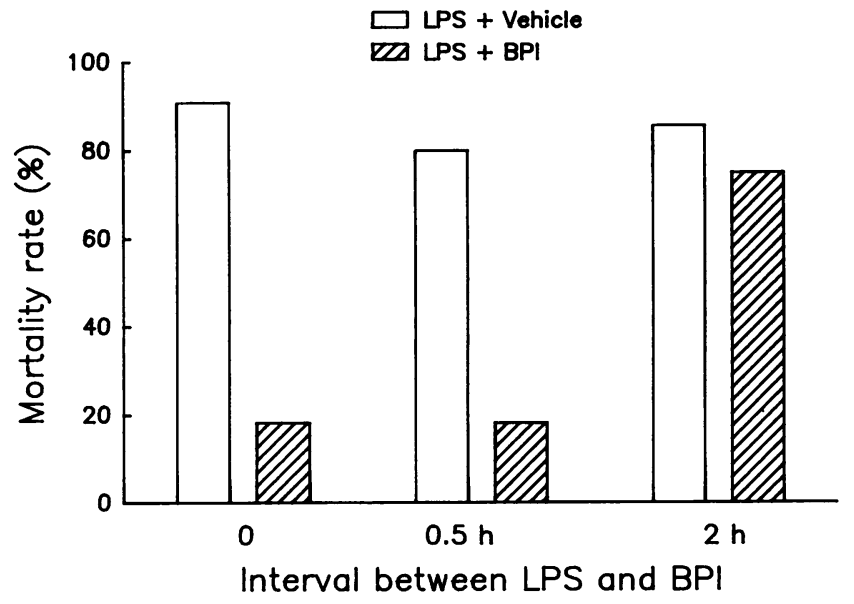

Figure 2. Effect of BPI treatment on mortality rate immediately, 30 min, or $2 \mathrm{~h}$ after LPS injection.

immediately after blood collection. Serum was separated and stored at $-70^{\circ} \mathrm{C}$ for the measurement of endotoxin, TNF, and IL-6.

Serum endotoxin was measured by a limulus amebocyte lysate assay, which was sensitive down to 0.5 endotoxin units $/ \mathrm{ml}$. Serum TNF was measured using a cell-based cytotoxicity assay, sensitive to $0.05 \mathrm{ng}$ of TNF. Serum IL-6 was measured using an IL-6-dependent B-9 hybridoma proliferation assay (20), sensitive to IL-6 at $0.05 \mathrm{ng} / \mathrm{ml}$.

Statistical analysis. Results were expressed as mean \pm SEM. The parameters at the same time point between the BPI and vehicle group were compared by an unpaired Student's $t$ test. The parameters in the same group among the different time points were compared by one way analysis of variance. $P<0.05$ was considered to be statistical significance.

\section{Results}

Effects of BPI given immediately after LPS. LPS administration resulted in a rapid decrease in MAP, which recovered briefly and then underwent a second transient decrease in the vehicletreated group (Fig. $1 \mathrm{~A}$ ). This early phase was followed by a larger, more sustained decrease in MAP over the next $8 \mathrm{~h}$. Administration of BPI immediately after LPS did not alter the initial transient falls in MAP but prevented the later sustained decrease. There was a significant difference in MAP at 4-8 h after LPS injection between the vehicle- and BPI-treated group $(P<0.01$, Fig. $1 A)$.

LPS administration rapidly increased $H R$, which reached a peak level at $2 \mathrm{~h}$, and thereafter remained at this plateau over the subsequent $6 \mathrm{~h}$ (Fig. $1 \mathrm{~B}$ ). BPI treatment attenuated the LPS-induced tachycardia significantly at $0.5-2.5 \mathrm{~h}$ but not at the later time points.

LPS caused death in $91 \%(10 / 11)$ of the vehicle-treated rats (Fig. 2), but only in $18 \%(2 / 11)$ of the BPI-treated rats.

MAP remained normal in all nine surviving rats in the BPItreated group and in the one surviving animal in the vehicletreated group for $6 \mathrm{~d}$ after the LPS injection (data not shown). The tachycardiac response to LPS lasted 2-3 d and then returned to normal in surviving rats in both groups (not shown).

Effects of BPI given 30 min after LPS. In this study set, LPS administration caused similar effects on MAP and HR in 

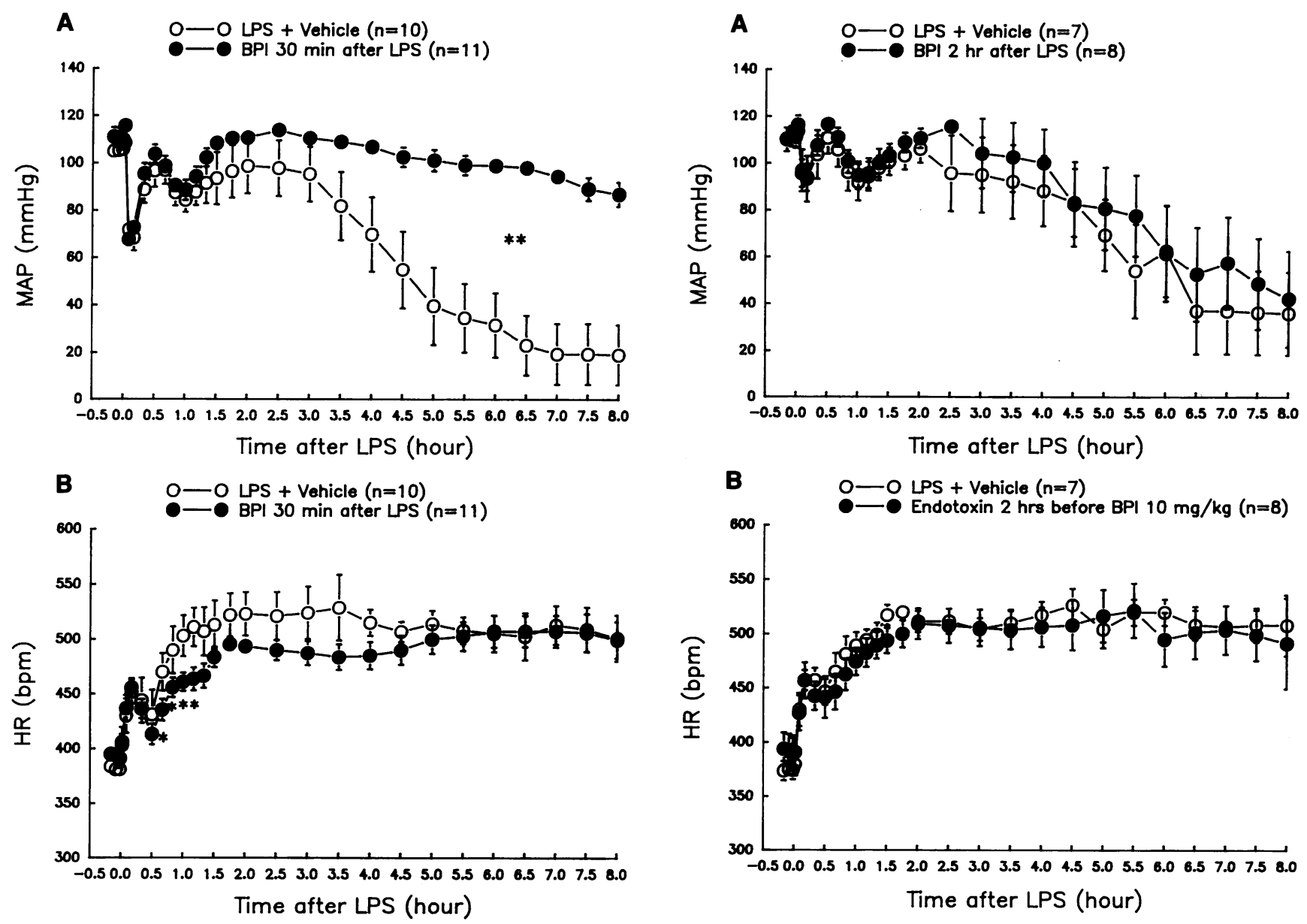

Figure 3. Effects of BPI treatment $30 \mathrm{~min}$ after LPS injection on MAP and HR. $* * P<0.01$, comparison of MAP at $4-8 \mathrm{~h}$ between the vehicleand BPI-treated group; $* P<0.05$, compared to the vehicle-treated group at the same time point.

the vehicle-treated animals as those described above (Fig. 3 ). BPI treatment $30 \mathrm{~min}$ after LPS injection significantly protected rats from the LPS-induced reduction in MAP measured 4-8 h after LPS injection. BPI also attenuated the LPS-induced tachycardiac response at $40-90 \mathrm{~min}$ after LPS, but not at other time points.

The mortality rate was $80 \%(8 / 10)$ and $18 \%(2 / 11)$ in the vehicle- and BPI-treated group, respectively (Fig. 2). MAP was stable for $6 \mathrm{~d}$ and tachycardia lasted $3 \mathrm{~d}$ in the surviving rats in both groups (data not shown).

Effects of BPI given $2 h$ after LPS. LPS induced alterations in MAP and HR (Fig. 4), essentially as shown above. BPI treatment $2 \mathrm{~h}$ after LPS injection did not significantly affect the LPS-induced hypotensive and tachycardiac responses. Furthermore, when given $2 \mathrm{~h}$ after LPS, BPI did not significantly reduce mortality. LPS caused $86 \%(6 / 7)$ mortality in the vehicletreated rats and $75 \%(6 / 8)$ in the BPI-treated rats (Fig. 2).

Serum endotoxin. Intravenous injection of LPS rapidly and markedly elevated the serum level of endotoxin in the vehicletreated rats (Fig. 5). Circulating endotoxin reached a peak level at $15 \mathrm{~min}$ and then declined by $50 \%$ at $45 \mathrm{~min}, 60 \%$ at $75-$ $120 \mathrm{~min}$, and $85 \%$ at $240 \mathrm{~min}$. BPI administration immediately

Figure 4. Effects of BPI treatment $2 \mathrm{~h}$ after LPS injection on MAP and HR.

after LPS injection significantly inhibited the LPS-induced increase in serum endotoxin (Fig. $5 A$ ). BPI lowered the endotoxin levels by $60 \%$ at $15 \mathrm{~min}$ and by more than $80 \%$ at 2-4 h.

Serum TNF. After injection of LPS, TNF in serum rose from undetectable levels to $11 \mathrm{ng} / \mathrm{ml}$ at $30 \mathrm{~min}$, to a peak level at $36 \mathrm{ng} / \mathrm{ml}$ at $90 \mathrm{~min}$, and then declined back to undetectable levels by $4 \mathrm{~h}$ (Fig. $5 \mathrm{~B}$ ). BPI administered immediately after LPS did not significantly affect the levels of TNF over the first $30 \mathrm{~min}$. However, thereafter, TNF rose to significantly higher levels in the BPI-treated animals than in control animals. It should be noted that the TNF detected was active, because it was measured by bioassay.

Serum IL-6. Serum levels of IL-6 rose significantly between 60 and 90 min after LPS injection and reached a peak level at $4 \mathrm{~h}$ (Fig. $5 C$ ). In BPI-treated animals, the LPS-induced rise in IL-6 levels began as in the vehicle-treated animals, reaching comparable levels at 90 min. However, thereafter, BPI attenuated the rise in IL-6 levels such that at $4 \mathrm{~h}$ the IL- 6 levels were $<25 \%$ of those in the vehicle-treated animals (Fig. $5 C$ ).

\section{Discussion}

BPI injected soon after LPS challenge markedly reduced mortality in this model of endotoxic shock. Early signs of efficacy 

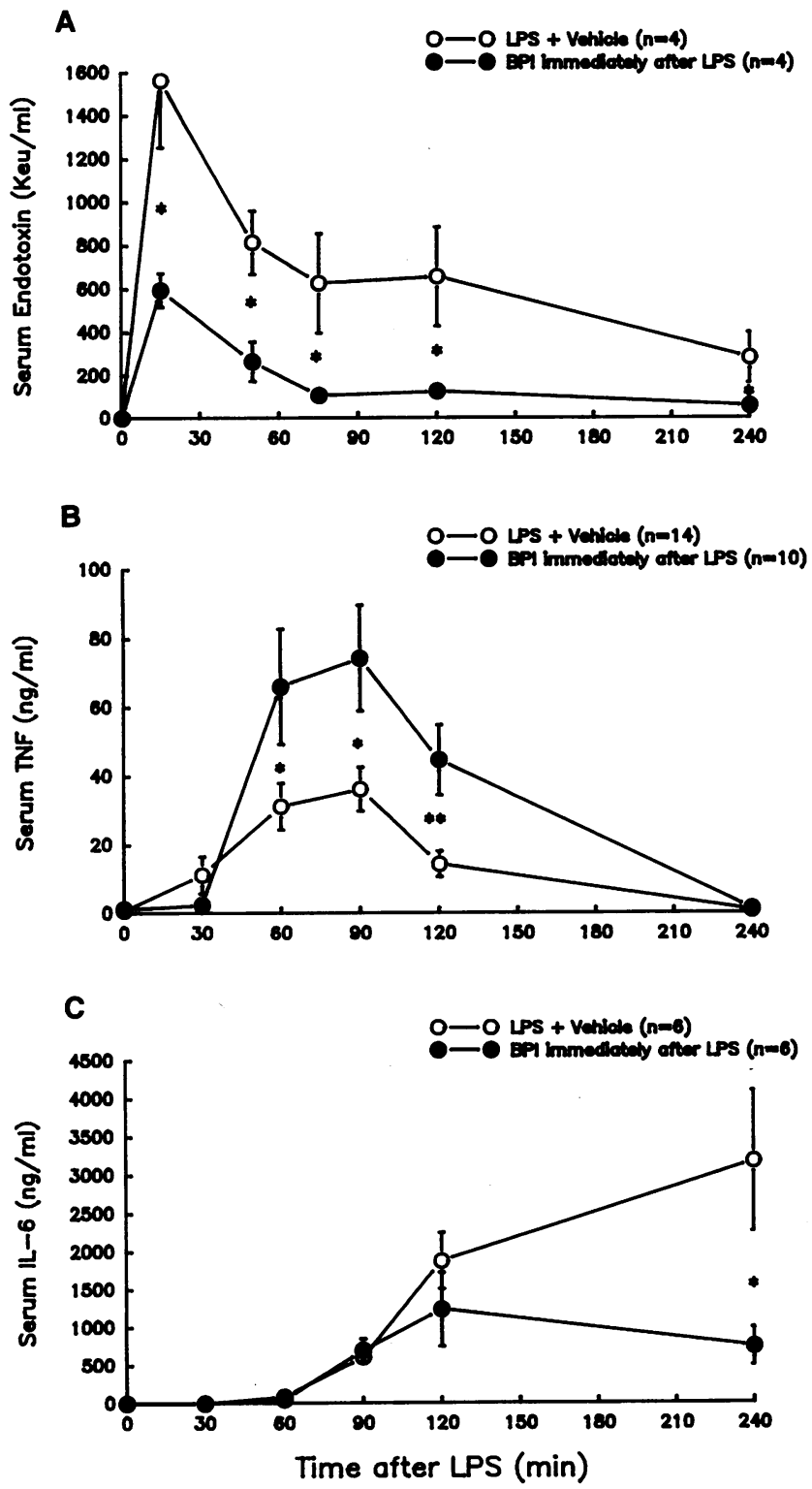

Figure 5. Effect of BPI treatment on serum levels of endotoxin, TNF, and IL-6 immediately after LPS injection. ${ }^{*} P<0.05, * * P<0.01$, comparison between the vehicle- and BPI-treated groups; Keu, 1,000 endotoxin units.

were prevention of the LPS-induced hypotension, reduction in circulating endotoxin levels, and inhibition of elevated circulating IL-6 levels. These results indicate that BPI may have potential value for treatment of Gram-negative septic shock.

The MAP pattern observed in the rat model described here shows two phases of shock: ( $a$ ) shock at the early phase, beginning at $5 \mathrm{~min}$ and recovering at 1.5-2 $\mathrm{h}$ after LPS injection; (b) shock at the late phase, beginning at 3.5-4 $\mathrm{h}$ after LPS and often leading to death. Heart rate was increased $5 \mathrm{~min}$ after LPS and thereafter remained at a substantially elevated level.

It has been shown that the LPS-induced reduction in blood pressure is associated with a decrease in cardiac output and stroke volume in conscious rats $(21,22)$, and tachycardia occurs as a compensatory response to maintain cardiac output and blood pressure. The current study demonstrated that, in the control animals, LPS caused a marked drop in blood pressure, despite a compensatory tachycardic response. In the BPI-treated animals, a similar tachycardic response was observed; however, in contrast to the controls, blood pressure remained stable. These data suggest that BPI may improve cardiac function by blocking detrimental effects of LPS on the heart.

In the current study, BPI treatment $2 \mathrm{~h}$ after LPS injection did not significantly affect LPS-induced hypotension, tachycardia, and lethality. This observation is consistent with the previous finding that BPI administered up to $1 \mathrm{~h}$ after LPS provides protection against lethal endotoxin challenge in mice (18). The narrow time window for protection may be attributed to the fact that, in models involving bolus injection of LPS, the highest circulating levels of endotoxin are achieved over the first $2 \mathrm{~h}$. Endotoxin at these levels may be irreversibly fatal. In our study, the circulating endotoxin in the vehicle-treated rats rose to a peak level $15 \mathrm{~min}$ after LPS injection and then decreased. At $2 \mathrm{~h}$, the circulating endotoxin level had declined to $40 \%$ of this peak level, which was close to the peak level of endotoxin observed in animals that were treated with BPI immediately after LPS injection.

Although BPI substantially reduced circulating endotoxin levels, its actions cannot be simply attributed to endotoxin neutralization. If that were the case, BPI would have been expected to suppress the endotoxin-induced rise in TNF levels. However, our data show that BPI actually increases circulating levels of bioactive TNF in the animals challenged with LPS. The increase in TNF levels may reflect a decrease in the TNF-stimulated production of soluble TNF receptors (TNF inhibitors) rather than an increase in TNF release. Indeed, Rogy et al. (23) have recently found that BPI significantly reduces circulating soluble TNF receptors in baboons with septic shock, supporting this explanation. Our observation that BPI protects against LPS lethality despite a rise in TNF levels suggests that BPI may exert its protective effect by neutralizing or counteracting a subset of, rather than all of the events triggered by, endotoxin.

TNF is thought to be one of the important mediators in septic shock. It has been reported that neutralizing antibodies against TNF or other agents that neutralize TNF protect animals against lethal endotoxin or $E$. coli challenge (24-28). In humans, TNF is released during the early stages of septic shock, and circulating TNF levels might correlate with outcome in severe sepsis (29-31). Nevertheless, some investigators have argued that TNF release is not the central mediator that is most directly responsible for sepsis $(32-35)$. It has been reported that administration of monoclonal antibody to endotoxin before lethal challenge with live $E$. coli protected animals from death but did not inhibit the rise in circulating TNF levels (33). Elevated TNF levels may be necessary but not sufficient for the lethal toxicity of endotoxin.

On the other hand, our data indicate that the protective effects of BPI may be due to its marked inhibition of IL-6 production, which was evident $4 \mathrm{~h}$ after LPS injection. A variety of published evidence links this cytokine to septic or endotoxic shock. Elevated serum IL-6 levels are found in the majority of patients with sepsis and show a strong positive correlation with mortality (36-39). In infants with sepsis, IL-6 levels are significantly increased, suggesting that plasma IL-6 is a specific indicator of sepsis (40). In addition, plasma IL-6 levels are significantly elevated in patients and chimpanzees with dissem- 
inated intravascular coagulation $(41,42)$, and anti-IL-6 antibodies inhibit endotoxin-induced activation of the coagulation system (42), suggesting that IL-6 may be a pivotal factor for coagulation activation. Further, several studies suggest that $\mathrm{IL}$ 6 may be a terminal mediator of pathological responses to septic shock (43-46). In $E$. coli-infected baboons, treatment with tissue factor pathway inhibitor prevents lethality and lowers IL6 levels but does not reduce elevated TNF levels (45). In mice with endotoxic shock, IL- 6 continues to circulate up to the time of death and correlates with outcomes, suggesting that IL-6 may serve as a prognostic marker for endotoxic shock (47). AntiIL-6 monoclonal antibodies protect mice against lethal $E$. coli infection or lethal TNF challenge, despite high circulating levels of TNF (46). Passive immunization against leukemia inhibitory factor (D factor) protects mice against the lethal effects of endotoxin and blocks the endotoxin-induced increase in serum IL-6 without altering the endotoxin-induced rise in serum levels of TNF (44). Thus, it seems a reasonable hypothesis that BPI exerts its protective effects in endotoxic shock by attenuating the production of IL-6 through a TNF-independent mechanism. Further studies should be directed to understanding how BPI inhibits endotoxin from stimulating IL-6 accumulation without preventing the rise in TNF levels.

\section{References}

1. Parrillo, J. E., M. M. Parker, C. Natanson, A. F. Suffredini, R. L. Danner, R. E. Cunnion, and F. P. Ognibene. 1990. Septic shock in humans: advances in the understanding of pathogenesis, cardiovascular dysfunction, and therapy. Ann. Intern. Med. 113:227-242.

2. Green, E. M., and H. R. Adams. 1992. New perspectives in circulatory shock: pathophysiologic mediators of the mammalian response to endotoxemia and sepsis. JAVMA (J. Am. Vet. Med. Assoc.). 200:1834-1841.

3. Hitchcock, P. J., L. Leive, P. H. Makela, E. T. Rietschel, W. Stritimatter, and D. C. Morrison. 1986. Lipopolysaccharide nomenclature-past, present, and future. J. Bacteriol. 166:699-705.

4. Duma, R. J. 1985. Gram-negative bacillary infections. Pathogenic and pathophysiologic correlates. Am. J. Med. 78(Suppl. 6A):154-164.

5. Kreger, B. E., D. E. Craven, and W. R. McCabe. 1980. Gram-negative bacteremia. IV. Re-evaluation of clinical features and treatment in 612 patients. Am. J. Med. 68:344-355.

6. Morrison, D. C., and R. J. Ulevitch. 1987. Endotoxins and disease mechanisms. Annu. Rev. Med. 38:417-432.

7. Shenep, J. L., and K. A. Mogan. 1984. Kinetics of endotoxin release during antibiotic therapy for experimental gram-negative bacterial sepsis. J. Infect. Dis. 150:380-388.

8. Pearson, F. C., J. Dubczak, M. Weaty, G. Bruszer, and G. Donohue. 1985 Detection of endotoxin in the plasma of patients with gram-negative bacterial sepsis by the limulus amoebocyte lysate assay. J. Clin. Microbiol. 21:865-868.

9. Nitsche, D., M. Kriewitz, A. Rossberg, and H. Hamelmann. 1987. The quantitative determination of endotoxin in plasma samples of septic patients with the clinical course of peritonitis using the chromogenic substrate and its correlation with clinical course of peritonitis. In Detection of Bacterial Endotoxins with the Lamellas Amoebocyte Lysate Test. S. W. Watson, J. Levin, and T. J. Novitsky, editors. Alan R. Liss Inc., New York. 417-429.

10. Brandtzaeg, P., P. Kierulf, P. Gaustad, A. Skulberg, J. N. Bruun, S. Halvorsen, and E. Sorensen. 1989. Plasma endotoxin as a predictor of multiple organ failure and death in systemic meningococcal disease. J. Infect. Dis. 159:195-204.

11. Weiss, J., S. Beckerdite-Quagliata, and P. Elsbach. 1980. Resistance of Gram-negative bacteria to purified bactericidal leukocyte proteins. Relation to binding and bacterial lipopolysaccharide structure. J. Clin. Invest. 65:619-628.

12. Weiss, J., K. Muello, M. Victor, and P. Elsbach. 1984. The role of lipopolysaccharides in the action of the bactericidal/permeability-increasing protein to target bacteria. J. Immunol. 132:3109-3115.

13. Mannion, B. A., E. S. Kalatzs, J. Weiss, and P. Elsbach. 1989. Preferential binding of the neutrophil granule-derived bactericidal/permeability-increasing protein to target bacteria. J. Immunol. 142:2807-2812.

14. Marra, M. N., C. G. Wilde, J. E. Griffith, J. L. Snable, and R. W. Scott.
1990. Bactericidal/permeability-increasing protein has endotoxin-neutralizing activity. J. Immunol. 144:662-666.

15. Ooi, C. E., J. Weiss, M. E. Doerfler, and P. Elsbach. 1991. Endotoxinneutralizing properties of the $25 \mathrm{kD}$ N-terminal fragment and a newly isolated 30 kD C-terminal fragment of the $55-60 \mathrm{kD}$ bactericidal/permeability-increasing protein of human neutrophils. J. Exp. Med. 174:649-655.

16. Marra, M. N., C. G. Wilde, M. S. Collins, J. L. Snable, M. B. Thornton, and R. W. Scott. 1992. The role of bactericidal/permeability-increasing protein as a natural inhibitor of bacterial endotoxin. J. Immunol. 148:532-537.

17. Weiss, J., P. Elsbach, C. Shu, J. Castillo, L. Grinna, A. Horwitz, and G. Theofan. 1992. Human bactericidal/permeability-increasing protein and a recombinant $\mathrm{NH}_{2}$-terminal fragment cause killing of serum-resistant Gram-negative bacteria in whole blood and inhibit tumor necrosis factor release induced by the bacteria. J. Clin. Invest. 90:1122-1130.

18. Fisher, C. J., M. N. Marra, J. E. Palardy, C. R. Marchbanks, R. W. Scott, and S. M. Opal. 1994. Human neutrophil bactericidal/permeability-increasing protein reduces mortality rate from endotoxin challenge: a placebo-controlled study. Crit. Care Med. 22:553-558.

19. Opal, S. M., C. J. Fisher, M. N. Marra, R. W. Scott, and J. E. Palardy. 1991. Bactericidal/permeability-increasing protein as a novel therapeutic modality in the treatment of endotoxin shock. Clin. Res. 30:511a. (Abstr.)

20. Brakenhoff, J. P., J. E. R. Degroot, R. F. Evers, H. Pannekock, and L. A. Aarden. 1987. Molecular cloning and expression of hybridoma growth factor in E. coli. J. Immunol. 139:4166-4121.

21. Brackett, D. J., C. F. Schaefer, P. Tompkins, L. Fagraeus, L. J. Peters, and M. F. Wilson. 1985. Evaluation of cardiac output, total peripheral vascular resistance, and plasma concentrations of vasopressin in conscious, unrestrained rats during endotoxemia. Circ. Shock. 17:273-284.

22. Biber, B., C. F. Schaefer, M. J. Smolik, M. R. Lerner, D. J. Brackett, M. F. Wilson, and L. Fagraeus. 1988. Improved techniques for cardiovascular monitoring in rats as applied during endotoxemia. Am. J. Physiol. 254:H181H186.

23. Rogy, M. A., H. S. A. Oldenburg, S. E. Calvano, W. J. Montegut, S. A. Stackpole, K. J. Van Zee, M. N. Marra, R. W. Scott, J. J. Seilhammmer, L. L. Moldawer, and S. F. Lowry. 1994. The role of bactericidal/permeability-increasing protein in the treatment of primate bacteremia and septic shock. J. Clin. Immunol. 14:120-133.

24. Beutler, B., I. W. Milsark, and A. C. Cerami. 1985. Passive immunization against cachectin/tumor necrosis factor protects mice from lethal effect of endotoxin. Science (Wash. DC). 229:869-871.

25. Tracey, K. J., Y. Fong, D. G. Hesse, K. R. Manogue, A. T. Lee, G. C. Kuo, S. F. Lowry, and A. Cerami. 1987. Anti-cachectin/TNF monoclonal antibodies prevent septic shock during lethal bacteraemia. Nature (Lond.). 330:662-664.

26. Silva, A. T., K. F. Bayston, and J. Cohen. 1990. Prophylactic and therapeutic effects of a monoclonal antibody to tumor necrosis factor- $\alpha$ in experimental gram-negative shock. J. Infect. Dis. 162:421-427.

27. Ashkenazi, A., S. A. Marsters, D. J. Capon, S. M. Chamow, I. S. Figari, D. Pennica, D. V. Goeddel, M. A. Palladino, and D. H. Smith. 1991. Protection against endotoxic shock by a tumor necrosis factor receptor immunoadhesin. Proc. Natl. Acad. Sci. USA. 88:10535-10539.

28. VanZee, K. J., T. Kohno, E. Fischer, C. S. Rock, L. L. Moldawer, and S. F. Lowry. 1992. Tumor necrosis factor soluble receptors circulate during experimental and clinical inflammation and can protect against excessive tumor necrosis factor in vitro and in vivo. Proc. Natl. Acad. Sci. USA. 89:4845-4849.

29. Waage, A., A. Halstensen, and T. Espevik. 1987. An association between tumor necrosis factor in serum and fatal outcome in patients with meningococcal disease. Lancet. i:355-357.

30. Girardin, E., G. E. Grau, J. M. Dayer, P. Roux-Lombard, and P. H. Lambert. 1988. Tumor necrosis factor and interleukin-1 in the serum of children with severe infectious purpura. N. Engl. J. Med. 319:397-400.

31. Debets, J. M. H., R. Kampmeijer, P. M. H. van der Linden, W. A. Buurman, and C. J. van der Linden. 1989. Plasma tumor necrosis factor and mortality in critically ill septic patients. Crit. Care Med. 17:489-494.

32. Bone, R. C. 1991. The pathogenesis of sepsis. Ann. Intern. Med. 115:457469.

33. Silva, A. T., B. J. Appelmelk, W. A. Buurman, K. F. Bayston, and J. Cohen. 1990. Monoclonal antibody to endotoxin core protects mice from Escherichia coli sepsis by a mechanism independent of tumor necrosis factor and interleukin-6 J. Infect. Dis. 162:454-459.

34. Smith, J. G., D. M. Magee, D. M. Williams, and J. R. Graybill. 1990. Tumor necrosis factor-alpha plays a role in host defence against Histoplasma capsulatum. J. Infect. Dis. 162:1349-1353.

35. Havell, E. D., and P. B. Sehgal. 1991. Tumor necrosis factor-independent IL-6 production during murine listeriosis. J. Immunol. 146:755-761.

36. Hack, C. E., E. R. de Groot, R. J. F. Felt-Bersma, J. H. Nuijens, R. J. M. Strack van Schijndel, A. J. M. Eerenberg-Belemer, L. G. Thijs, and L. A. Aarden. 1989. Increased plasma levels of interleukin-6 in sepsis. Blood. 74:1704-1710.

37. Waage, A., P. Brandtzaeg, A. Halstensen, P. Kierulf, and T. Espevik. 
1989. The complex pattern of cytokines in serum from patients with meningococcal septic shock. Association between interleukin 6, interleukin 1, and fatal outcome. J. Exp. Med. 169:333-338.

38. Waage, A., T. Espevik, and A. Halstensen. 1988. TNF, IL-1, and IL-6 in human septic shock. Scand. J. Immunol. 28:267-271.

39. Sullivan, J. S., L. Kilpatrick, A. T. Costarino, S. C. Lee, and M. C. Harris. 1992. Correlation of plasma cytokine elevation with mortality rate in children with sepsis. J. Pediatr. 120:510-515.

40. Harris, M. C., A. T. Costarino, J. S. Sullivan, S. Dulkerian, L. McCawley, L. Corcoran, S. Butler, and L. Kilpatrick. 1994. Cytokine elevation in critically ill infants with sepsis and necrotizing enterocolitis. J. Pediatr. 124:105-111.

41. Wada, H., M. Tanigawa, Y. Wakita, T. Nakase, K. Minamikawa, T. Kaneko, M. Ohiwa, S. Kageyama, T. Kobayashi, T. Noguchi, et al. 1993. Increased plasma level of interleukin- 6 in disseminated intravascular coagulation. Blood Coagul. \& Fibrinolysis. 4:583-590.

42. van der Poll, T., M. Levi, C. E. Hack, H. ten Cate, S. J. H. van Deventer, A. J. M. Eerenberg, E. R. de Groot, J. Jansen, H. Gallati, H. R. Büller, et al. 1994.
Elimination of interleukin 6 attenuates coagulation activation in experimental endotoxemia in chimpanzees. J. Exp. Med. 179:1253-1259.

43. McNamara, M. J., J. A. Norton, R. J. Nauta, and H. R. Alexander. 1993. Interleukin-1 receptor antibody (IL-1 rab) protection and treatment against lethal endotoxemia in mice. J. Surg. Res. 54:316-321.

44. Block, M. I., M. Berg, M. J. McNamara, J. A. Norton, D. L. Fraker, and H. R. Alexander. 1993. Passive immunization of mice against D factor blocks lethality and cytokine release during endotoxemia. J. Exp. Med. 178:1085-1090.

45. Creasey, A. A. A. C. K. Chang, L. Feigen, T.-C. Wün, F. B. Taylor, Jr., and L. B. Hinshaw. 1993. Tissue factor pathway inhibitor reduces mortality from Escherichia coli septic shock. J. Clin. Invest. 91:2850-2860.

46. Starnes, H. F., M. K. Pearce, A. Tewari, J. H. Yim, J.-C. Zou, and J. S. Abrams. 1990. Anti-IL-6 monoclonal antibodies protect against lethal Escherichia coli infection and lethal tumor necrosis factor- $\alpha$ challenge in mice. J. Immunol. 145:4185-4191.

47. Kelly, N. M., and A. S. Cross. 1992. Interleukin-6 is a better marker of lethality than tumor necrosis factor in endotoxin treated mice. FEMS (Fed. Eur. Microbiol. Soc.) Microbiol. Immunol. 4:317-322. 